\title{
Na prahu nové doby: zpráva o Mezioborové konferenci o počátcích Československé republiky
}

Rok 2018 přinesl zásadní výročí sta let, uplynulých od vzniku Československé republiky, jedné z nejvýznamnějších událostí dosavadních českých a středoevropských dějin. Pokusili jsme se s kolegou Vítem Strobachem připravit konferenci, která by svým pojetím odpovídala zásadnímu významu roku 1918 pro obyvatelstvo střední Evropy i pro pozdější desetiletí. Rok 1918 neznamenal jen obnovu a vznik samostatného státu, nastolení republikánského zřízení, demokratického politického systému, zrušení stavovských privilegií a další krok na cestě $\mathrm{k}$ rovnosti žen a mužů, ale také další etapu národní emancipace i otevření nových možností změny sociální, hospodářské a kulturní situace pro rozsáhlé skupiny obyvatelstva. Rok 1918 znamenal více, než kterýkoli jiný rok v českých a slovenských dějinách, představoval okamžik zlomu, který byl předpokladem mnoha změn dalších a pozdějších. Zároveň jsme chtěli připravit konferenci, která by byla v lecčems podnikem atypickým, překračujícím navyklé formáty jednotlivých oborů i obvyklé způsoby organizace. Vedle jiných konferencí oborových, jejichž uspořádání bylo možné očekávat, jsme se snažili připravit konferenci odlišnou - mezioborovou, na které by se ve vzájemném dialogu mohli setkat vědci z různých oblastí výzkumu. Nechtěli jsme přijmout nabízející se formu obvyklé, tradičně pojaté konference, obroubené v tomto prípadě ještě i oslavnými pentlemi, ale spiśs ověřit formou experimentu možnosti a hranice mezioborového pojetí. Zároveň mělo jít i o konferenci široce otevřenou i zájemcům z řad veřejnosti, čemuž odpovídalo i celkové pojetí a výběr místa pro konání konference, stejně jako pojetí doprovodných akcí.

Z hlediska tematického byla konference Na prahu nové doby ${ }^{1}$ strukturována na základě vymezených konferenčních okruhů, označených pomocí písmen $\mathrm{A}$ až $\mathrm{J}, \mathrm{v}$ jejichž rámci byly připraveny a formou výzvy $k$ přihlašování př́spěvků vypsány tematické sekce (označované dle okruhu např. A2, B2, B4, apod.). Struktura okruhů a sekcí tak, jak se s mírnými úpravami na konferenci uskutečnily, vypadala takto: Tematický okruh A: Diference, zájmy, stratifikace (sekce A1: Sociální politika ve středoevropských společnostech poválečných let; sekce A2: Bydlení a architektura ve středoevropském poválečném myšlení; sekce A3: Práce - spory - stávky; sekce A5: Životní úroveň a trávení volného času; sekce A6: Náboženství versus sekularita), tematický okruh B: Kulturní stát? (sekce B2: Novou školou k novému světu? Boje o školskou reformu a školské pokusy; sekce B3: Vědní

1 Samotný název konference byl odvozen z názvu úvahy napsané Václavem Horou, profesorem pražské právnické fakulty, otevírající v lednu 1919 nový ročník časopisu Právník. 
a vysokoškolská politika; sekce B4: Umění, stát a reprezentace; sekce B5: Film jako popkulturní fenomén a průmyslové odvětví; sekce B6: Uchovávající republika: změny a vize v archivnictví a památkářství). Tematický okruh C: Hranice - centrum - periferie (sekce $\mathrm{C} 1$ : Bratr, investor, kolonista? Východ ČSR - přístupy a reflexe; sekce C2: Proměna hranic hospodářského prostoru a komunikačních sítí: pohyb a energie na jiných cestách; sekce C3: Migrace - př́islušnosti - azyl). Tematický okruh D: Právní, hospodářské a správní struktury (sekce D1: Republika právníků? Právnické profesní světy; sekce D2: Místní moc v počátcích republiky mezi setrvalostí a změnou; sekce D3: Sjednocování práva; sekce D4: Hospodářská samostatnost a hospodářský nacionalismus; sekce D5: Státní struktury: správa, samospráva a jejich úřednictvo; sekce D6: Hospodářská moc, její struktura, zájmy a dynamika). Tematický okruh E: Spory o nadvládu a emancipaci (sekce E1: „Politicky, sociálně a kulturně rovné?" Nesnadná emancipace žen v poválečné společnosti; sekce E2: Národnostní otázka - dobový diskurz, reflexe, konflikty; sekce E3: Sexuální reforma: osvobozené city, osvobozená těla; sekce E4: Zdraví, sociální hygiena a postižení; sekce E5: Romové a židé: represe, emancipace a možnosti srovnání?). Tematický okruh F: Právněteoretické, filosofické a politické rámce (sekce F1: Nová ústavněprávní řešení ve středoevropských ústavách a praxi 20. let; sekce F2: Povaha práva očima středoevropské právní teorie a právní filosofie dvacátých let). Tematický okruh G: Československo: mezinárodní projekt (sekce G1: Mezinárodní zajištění vzniku státu a počátky jeho diplomacie; sekce G2: Nové cesty ve střední Evropě). Tematický okruh H: Trestání, násilí a ozbrojenost (sekce H2: Proměny státních ozbrojených sborů). Tematický okruh J: Minulost a budoucnost: politika paměti, filosofie dějin a představy nového (sekce J1: Československo jako uskutečnění filosofie českých dějin?; sekce J2: Nově utvářená a odstraňovaná místa paměti - fyzické a symbolické prostory).

Spolupořadateli konference se vedle Ústavu státu a práva AV ČR staly Ústav štátu a práva Slovenskej akadémie vied, Ústav právních dějin Právnické fakulty Univerzity Karlovy, Filozofická fakulta Univerzity Karlovy, Filosofický ústav Akademie věd České republiky a Ústav dějin umění Akademie věd České republiky. Konference byla čtyřdenní, přičemž dva konferenční dny vyšly na sobotu a neděli (svátek 28. ř́jjna), zbylé dva pak na pátek a pondělí. Na počátku konference účastníky přivítali velvyslanec Slovenské republiky u nás Peter Weiss, místopředseda Ústavního soudu Jaroslav Fenyk a předseda Vědecké rady AV ČR Antonín Fejfar.

Prvý oddíl (blok) konference byl pojat jako společný a odehrával se ve velkém sále, přičemž z kapacitních prŕíčin byl přenos z něho promítán i ještě do vedlejšího středního sálu. Byli jsme velmi rádi, že odborná část konference mohla být zahájena nejdůstojnějším možným zpo̊sobem - příspěvky nejvýznamnějších osobností z různých oborů. Karel Malý zahájil společný oddíl konference přednáškou o utváření demokratické podoby československé republiky a o překonávání monarchistických tradic. Miroslav Hroch navázal s příspěvkem o problematice národního státu, Jan Kuklík přiblížil mezinárodní souvislosti vzniku československého státu, Libuše Heczková hovořila o způsobech myšlení o ženách v meziválečné československé společnosti. Společný oddíl konference uzavřel Stanislav Holubec s prríspěvkem o historiografickém zkoumání meziválečné republiky v posledních desetiletích.

Podrobný popis příspěvků, které zazněly v jednotlivých sekcích, se vymyká prostorovým možnostem obvyklé zprávy o konferenci. Přehled tohoto druhu lze ovšem získat 
jednak z konferenční brožury (vydané česky i anglicky), ${ }^{2}$ a ve větších podrobnostech pak dále i v samostatné publikaci se shrnutími jednotlivých př́spěvků z pera jejich autorů a autorek. ${ }^{3}$

Celkem se konference zúčastnilo na 170 přednášejících v 31 sekcích. Dalších více než 100 účastníků bylo přihlášeno a účastnilo se bez příspěvku. Další účastníci se zúčastnili nepřihlášeni. Celkově lze účast odhadnout na nejméně 300-320 osob. O konferenci projevila zájem i média, na společném konferenčním bloku krátce natáčela Česká televize, byl přítomen zpravodaj Českého rozhlasu. Dodejme ještě, že konferenci př́ijemně doplnila večerní promítání historických filmů pro účastníky i širokou veřejnost v nedalekém kině Ponrepo, zařízení Národního filmového archivu; promítány byly jak filmy hrané, tak i dokumenty. Dále byla připravena komentovaná historická procházka po centru města. Všem, kteří se podíleli na organizaci této konference, bych tímto rád poděkoval za vysoké nasazení a skvělou součinnost. Př́íspěvky z konference budou v dohledné době publikovány.

Jan Kober

doi: $10.14712 / 2464689 X .2019 .44$

2 Mezioborová konference o počátcích Československé republiky Na prahu nové doby. Program. Praha: Ústav státu a práva AV ČR, 2018, 44 s.; Interdisciplinary Conference on the Beginnings of the Czechoslovak Republic On the Threshold of a New Era. Programme. Prague: Institute of State and Law, CAS, 2018, $47 \mathrm{~s}$.

3 KOBER, J. - STROBACH, V. (eds.). Shrnuti př́spěvků. Mezioborová konference Na prahu nové doby. 26. 10. 2018 až 29. 10. 2018. Praha: Ústav státu a práva AV ČR, 2018, 84 s. 